\title{
Changes in nutrient and heavy metal content levels of sawdust due to vermicomposting by Allomyrina dichotoma subsp. tunobosonis
}

\author{
Chinh Nguyen Hoang ${ }^{1}$, Zhi-Wei Yang ${ }^{2}$, Meng-Yuan Huang ${ }^{3}$ *, \\ KuAN-Hung LIN $^{3}{ }^{*}$, ChI-Ming YANG ${ }^{4}$, Minh KHIEM NGUYeN ${ }^{1}$ \\ ${ }^{1}$ Faculty of Applied Sciences, Ton Duc Thang University, Ho Chi Minh City, Vietnam \\ ${ }^{2}$ Taoyuan District Agricultural Research and Extension Station, Council of Agriculture, Taoyuan, Taiwan \\ ${ }^{3}$ Department of Horticulture and Biotechnology, Chinese Culture University, Taipei, Taiwan \\ ${ }^{4}$ Biodiversity Research Center, Academia Sinica, Taipei, Taiwan
}

\begin{abstract}
Vermicomposting of organic waste plays an important role in integrated waste management and sustainable agricultural development. This study aimed at investigating the transformation of nutrients and heavy metals during vermicomposting of fermented sawdust substrate using the beetle Allomyrina dichotoma subsp. tunobosonis. By the end of vermicomposting, the substrate was significantly modified, with increase in $\mathrm{pH}$ and decrease in both organic matter and electrical conductivity. Potassium oxide $\left(\mathrm{K}_{2} \mathrm{O}_{5}\right)$ content was found to have significantly increased, whereas no significant difference in the quantities of other nutrients $\left(\mathrm{N}_{2} \mathrm{P}_{2} \mathrm{O}_{5}, \mathrm{CaO}\right.$ and $\left.\mathrm{MgO}\right)$ was observed between the substrate and vermicompost. In addition, $\mathrm{Cd}$ content significantly decreased compared to other heavy metals $(\mathrm{Cu}, \mathrm{Zn}, \mathrm{Cr}, \mathrm{Ni}$, and $\mathrm{Pd}$ ) during vermicomposting. These findings suggest that the produced vermicompost, with low concentrations of heavy metals, may be a suitable potting medium for plant growth.
\end{abstract}

Key words: Allomyrina dichotoma, vermicompost, nutrient, heavy metal

\section{Introduction}

Vermicomposting is an eco-friendly, biotechnological process that recycles biodegradable organic waste into a stabilized humus-like product by employing earthworms and microorganisms, thus generating a stable and homogenous product called vermicompost. Vermicompost is considered a valuable and marketable plant growth product since nutrients are converted and released from organic waste during the vermicomposting process. In addition, the generated product has reduced levels of contaminants, thus making it a desirable product for agricultural use (Ndegwa and Thompson, 2001). Sawdust, a by-product generated in large amounts in agricultural and industrial processes, can be recycled for land applications. Therefore, recycling of sawdust for agricultural use is usually the most convenient and economical disposal alternative for reducing the use of inorganic fertilizers.

Several technologies have been developed to convert organic materials into vermicompost using earthworms. However, the aerobic composting process increases the complexation of heavy metals in organic waste residues (Kang et al., 2011; Wong and Selvam, 2006). Vermistabilization of sewage sludge results in increase in heavy metal content of vermicompost, thus affecting its quality (Khwairakpam and Bhargava, 2009; Suthar, 2010). Bioavailable metal fractions are critical from the perspective of ecotoxicology and environmental risk (Fuentes et al., 2006). With the use of vermicompost, transport of heavy metals to agricultural crops has become a matter of concern due to their long residence times, toxicity to plants and soil microbial processes, and potential negative ef-

\footnotetext{
* Correspondence authors: Department of Horticulture and Biotechnology, Chinese Culture University, Taipei, Taiwan; e-mail: hmy6@ulive.pccu.edu.tw; rlin@faculty.pccu.edu.tw; nguyenhoangchinh@tdtu.edu.vn
} 
fects exerted on animals and humans. Therefore, the development of eco-friendly techniques to improve the solubility of plant nutrients while reducing heavy metal content has attracted several investigations (Hait and Tare, 2012; Mupondi et al., 2018; Wang et al., 2017).

Allomyrina dichotoma subsp. tunobosonis, a species of the Coleoptera family, is found in Taiwan (Rowland, 2003) and was recently considered an alternative insect for processing organic waste. However, no study has examined the availability of nutrients and heavy metals during vermicomposting using $A$. dichotoma. Therefore, this study investigated the transformation and availability of nutrients (N, P, K, $\mathrm{Ca}$, and $\mathrm{Mg}$ ) and heavy metals $(\mathrm{Cu}, \mathrm{Zn}, \mathrm{Cr}, \mathrm{Ni}, \mathrm{Cd}$, and $\mathrm{Pd})$ during vermicomposting of fermented sawdust by employing $A$. dichotoma subsp. tunobosonis.

\section{Materials and methods}

\section{Insects and vermicomposting process}

A. dichotoma subsp. tunobosonis was provided by a local beetle store (Xichong Tian Jiang, New Taipei, Taiwan). The third instar larva was used as inoculant in the study. Maple and oak sawdust was fermented for 60 days under aeration with sugar and water before being used in the study. The vermicomposting process was performed in plastic containers $(30 \times 20 \times 20 \mathrm{~cm})$ with pierced lids for aeration. Approximately $1.5 \mathrm{~kg}$ of the fermented sawdust (maple:oak in 1:1 ratio w/w) was put into the containers to serve as bedding and food for A. dichotoma, followed by culturing under controlled environmental conditions for 1 month. Six plastic containers were placed in a growth chamber in three layers, with two boxes in each layer. The growth chamber was set at $25^{\circ} \mathrm{C}$, and the moisture level of the sawdust was maintained at $55 \%$. After 1 month, the vermicompost was collected for analysis of changes in nutrients and heavy metal content.

\section{Determination of changes in nutrient and heavy metal content in the substrate before and after vermi composting}

Total organic carbon and total Kjeldahl nitrogen (N) were determined using the methods of Nelson and Sommers (1982) and Bremner and Mulvaney (1982), respectively. Organic matter $(\mathrm{OM})$ was decomposed with a mixture of acids $\left(\mathrm{HNO}_{3}: \mathrm{HClO}_{4}\right)$ in $5: 1$ ratio. The phosphorus oxide $\left(\mathrm{P}_{2} \mathrm{O}_{5}\right)$ content of the filtrate was then ana- lyzed using the Murphy and Riley method (1962). The potassium oxide $\left(\mathrm{K}_{2} \mathrm{O}_{5}\right)$ content was measured by flame spectrophotometry (Model 410; Sherwood Scientific, Cambridge, UK) as described by Knudsen et al. (1982). Calcium oxide $(\mathrm{CaO})$ and magnesium oxide $(\mathrm{MgO})$ contents were determined by inductively coupled plasma (ICP) spectrometry (5100 ICP-OES; Agilent Technologies, Santa Clara, CA, USA) according to the procedures of Flannery and Markus (1980). The content of heavy metals, namely, $\mathrm{Cu}, \mathrm{Zn}, \mathrm{Ni}, \mathrm{Cr}, \mathrm{Cd}$, and $\mathrm{Pb}$, was determined by ICP spectrometry after digesting the sample in a diacid mixture (concentrated $\mathrm{HNO}_{3}$ : concentrated $\mathrm{HClO}_{4}$, $4: 1$, v/v) (Pansu, 2001). $\mathrm{pH}$ and electrical conductivity (EC) were measured using a $\mathrm{pH}$ meter $(\mathrm{pH}$ version 6071; Jenco Electronics, San Diego, CA, USA) and a conductivity meter (model CDM 210; Radiometer, Cedex, France), respectively.

\section{Statistical analysis}

All experiments were performed in triplicate and results were expressed as mean \pm standard deviation. An analysis of variance with the least significant difference (LSD) test at $P \leq 0.05$ was performed using SAS version 9 (SAS Institute, Cary, NC, USA).

\section{Results and discussion}

\section{Changes in the physical properties of the substrates}

Table 1 shows that the physical properties of the substrate significantly changed during the vermicomposting process. OM content and EC decreased significantly, from 71.45 to $64.6 \%$ and from 2.42 to 1.63 , respectively, whereas the $\mathrm{pH}$ value of the substrate increased from 7.28 to 7.68 by the end of the vermicomposting period.

Table 1. Physical properties of the substrate and vermicompost

\begin{tabular}{c|c|c}
\hline Value & Substrate & Vermicompost \\
\hline $\mathrm{pH}$ & $7.28 \pm 0.16^{\mathrm{b}}$ & $7.68 \pm 0.31^{\mathrm{a}}$ \\
\hline EC & $2.42 \pm 0.33^{\mathrm{a}}$ & $1.63 \pm 0.11^{\mathrm{b}}$ \\
\hline OM $[\%]$ & $71.45 \pm 1.10^{\mathrm{a}}$ & $64.60 \pm 4.59^{\mathrm{b}}$ \\
\hline
\end{tabular}

Values in the same row with different letters differ significantly $(P<0.05)$

The vermicomposting process resulted in appreciable modification of the physical profile of the substrate due 


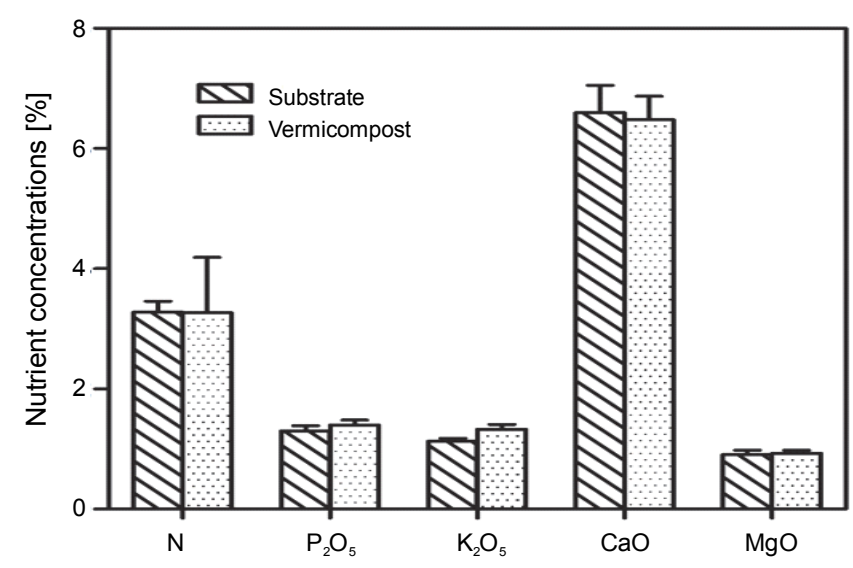

Fig. 1. Nutrient content of the substrate compared to vermicompost

to the activity of $A$. dichotoma. A higher OM content of the substrate than that of the vermicompost suggests that $\mathrm{OM}$ mineralization was rapidly attained through the insect's activity during vermicomposting. The loss of $\mathrm{OM}$ was a consequence of converting it into insect biomass via its digestive system. A lower EC value with a higher $\mathrm{pH}$ for the vermicompost compared to the initial substrate indicates that the vermicompost obtained in the study was suitable as potting media for plant growth, and further changes in the $\mathrm{pH}$ may make it suitable for horticultural crops (Verdonck et al., 1987).

\section{Changes in the nutrients of the substrate}

Figure 1 displays the changes in the nutrient content of the substrate during vermicomposting. $\mathrm{N}, \mathrm{P}_{2} \mathrm{O}_{5}, \mathrm{CaO}$, and $\mathrm{MgO}$ content did not significantly differ between the substrate and vermicompost, whereas the macronutrient $\mathrm{K}_{2} \mathrm{O}_{5}$ content in the vermicompost (1.34\%) was significantly higher than that of the substrate (1.12\%). Previous studies have indicated increase in $\mathrm{N}, \mathrm{P}, \mathrm{Ca}$, and $\mathrm{Mg}$ content during vermicomposting of sludge (Hait and Tare, 2011; Kaur et al., 2010). Nevertheless, our results differ from the results of those studies, perhaps due to the use of a different substrate for vermicomposting. Additionally, a large number of microorganisms were found to play an important role in transforming various plant nutrients into more soluble and available forms during vermicomposting (Sharma, 2003; Suthar and Singh, 2008). Hence, the differences observed in the amount of macronutrients between the substrate and vermicompost depend to a large degree on microorganism populations present in the mixture.

\section{Changes in the heavy metal content of the substrates}

Reducing the content of heavy metals in organic waste using insects is an industrially important process. It is necessary to determine the heavy metal content of vermicompost due to its toxicity to plants, soil microbial processes, and potential negative side-effects on humans and animals (Whittle and Dyson, 2002).

Table 2. Heavy metal content (\%) of the substrate and vermicompost

\begin{tabular}{c|c|c}
\hline $\begin{array}{c}\text { Heavy } \\
\text { metal }\end{array}$ & Substrate & Vermicompost \\
\hline $\mathrm{Cu}$ & $13.15 \pm 0.74^{\mathrm{a}}$ & $12.73 \pm 0.66^{\mathrm{a}}$ \\
\hline $\mathrm{Zn}$ & $69.75 \pm 3.43^{\mathrm{a}}$ & $71.32 \pm 1.74^{\mathrm{a}}$ \\
\hline $\mathrm{Cd}$ & $0.46 \pm 0.06^{\mathrm{a}}$ & $0.38 \pm 0.00^{\mathrm{b}}$ \\
\hline $\mathrm{Ni}$ & $6.53 \pm 0.16^{\mathrm{a}}$ & $6.76 \pm 0.50^{\mathrm{a}}$ \\
\hline $\mathrm{Cr}$ & $4.09 \pm 0.19^{\mathrm{a}}$ & $4.25 \pm 0.45^{\mathrm{a}}$ \\
\hline $\mathrm{Pb}$ & $3.25 \pm 0.29^{\mathrm{a}}$ & $3.43 \pm 1.14^{\mathrm{a}}$ \\
\hline
\end{tabular}

Values in the same row with different letters differ significantly $(P<0.05)$

Table 2 shows that $\mathrm{Cd}$ content between the substrate and vermicompost decreased significantly from 0.46 to $0.38 \%$, whereas no significant differences in other heavy metal concentrations $(\mathrm{Cu}, \mathrm{Zn}, \mathrm{Ni}, \mathrm{Cr}$, and $\mathrm{Pb})$ were observed. Furthermore, $\mathrm{Cr}, \mathrm{Ni}$, and $\mathrm{Pd}$ were detected at low concentrations $(<7 \%)$ compared to $\mathrm{Cu}(12.73 \%)$ and $\mathrm{Zn}$ $(71.32 \%)$ in vermicompost. Our results differ from those of other studies thatshowed increase in heavy metal content during vermicomposting of sludge (Bakar et al., 2011; Hait and Tare, 2012; Kaur et al., 2010). However, the reduction in Cd is in agreement with the findings of Suthar (2009), who also reported a decrease in $\mathrm{Cu}$ and $\mathrm{Zn}$ concentrations during vermicomposting of sewage sludge spiked with sugarcane trash. Like earthworms, A. dichotoma may also reduce the bioavailability and mobility of heavy metals, especially Cd (Cherian and Nordberg, 1983), thus restricting the release of heavy metals during vermicomposting (Dai et al., 2004; Langdon et al., 2003). In addition, the produced vermicompost can be used for agricultural crops since the heavy metal content meets the specifications of compost standards (CEC, 1986; CPHEEO, 2000; USEPA, 1994), indicating that the produced vermicompost was fit for agriculture use. 


\section{Conclusions}

Vermicomposting using $A$. dichotoma significantly changed the physical properties of the substrate $(\mathrm{pH}$, $\mathrm{OM}$, and EC). After the vermicomposting process, the content of $\mathrm{K}_{2} \mathrm{O}_{5}$ in the vermicomposted product had increased significantly in comparison with the initial substrate, and the content of one heavy metal (Cd) had decreased significantly. Therefore, the produced vermicompost can be used as a suitable potting medium for plant cultivation.

\section{References}

Bakar A.A., Mahmood N.Z., Da Silva J.A., Abdullah N., Jamaludin A.A. (2011) Vermicomposting of sewage sludge by Lumbricus rubellus using spent mushroom compost as feed material: Effect on concentration of heavy metals. Biotech. Biopro. Engin. 16: 1036-1043.

Bremner J.M., Mulvaney R.G. (1982) Nitrogen total. [in:] Method of soil analysis. Ed. Page A.L., Miller R.H., Keeney D.R. Amer. Soc. Agron., Madison.

Cherian M.G., Nordberg M. (1983) Cellular adaptation in metal toxicology and metallothionein. Toxicology 28: 1-15.

CPHEEO (2000) Manual on municipal solid waste management. Central Public Health and Environmental Engineering Organization, New Delhi.

Dai J., Becquer T., Rouiller J.H., Reversat G., Bernhard-Reversat F., Nahmani J., Lavelle P. (2004) Heavy metal accumulation by two earthworm species and its relationship to total and DTPA-extractable metals in soils. Soil Biol. Biochem. 36: 91-98.

CEC (The Council of the European Communites) (1986) Council directive on the protection of the environment, and in particular of the soil, when sewage sludge is used in agriculture. Official J. Europ. Comm. 181: 6-12.

Flannery R.L., Markus D.K. (1980) Automated analysis of soil extracts for phosphorus, potassium, calcium, and magnesium. J. Ass. Offic. Analyt. Chem. (USA).

Fuentes A., Llorens M., Saez J., Aguilar M.I., Pérez-Marín A.B., Ortuño J.F., Meseguer V.F. (2006) Ecotoxicity, phytotoxicity and extractability of heavy metals from different stabilized sewage sludges. Environ. Pollu. 143: 355-360.

Hait S., Tare V. (2011) Vermistabilization of primary sewage sludge. Bioresour. Tech. 102: 2812-2820.

Hait S., Tare V. (2012) Transformation and availability of nutrients and heavy metals during integrated composting - vermicomposting of sewage sludges. Ecotox. Ecotox. Environ. Safety 79: 214-224.

Kang J., Zhang Z., Wang J.J. (2011) Influence of humic substances on bioavailability of $\mathrm{Cu}$ and $\mathrm{Zn}$ during sewage sludge composting. Biores. Tech. 102: 8022-8026.

Kaur A., Singh J., Vig A.P., Dhaliwal S.S., Rup P.J. (2010) Cocomposting with and without Eiseniafetida for conversion of toxic paper mill sludge to a soil conditioner. Biores. Tech. 101: 8192-8198.
Khwairakpam M., Bhargava R. (2009) Vermitechnology for sewage sludge recycling. J. Hazard. Mater. 161: 948-954.

Knudsen D., Peterson G.A, Pratt P.F. (1982) Lithium, sodium, and potassium. Part 2: Chemical and microbiological properties. Meth. Soil Anal. 595: 225-246.

Langdon C.J., Piearce T.G., Meharg A.A., Semple K.T. (2003) Interactions between earthworms and arsenic in the soil environment: a review. Environ. Pollu. 124: 361-373.

Mupondi L.T., Mnkeni P.N., Muchaonyerwa P., Mupambwa H.A. (2018) Vermicomposting manure-paper mixture with igneous rock phosphate enhances biodegradation, phosphorus bioavailability and reduces heavy metal concentrations. Heliyon 4: e00749.

Murphy J., Riley J.P. (1962) A modified single solution method for the determination of phosphate in natural waters. Anal. Chim. Acta 27: 31-36.

Ndegwa P., Thompson S. (2001) Integrating composting and vermicomposting in the treatment and bioconversion of biosolids. Biores. Tech. 76: 107-112.

Nelson D.W., Sommers L.E. (1982) Total carbon and organic carbon and organic matter. [in:] Method of soil analysis. Ed. Page A.L., Miller R.H., Keeney D.R. American Society of Agronomy, Madison.

Pansu M., Gautheyrou J., Loyer J.Y. (2001) Soil analysis. Taylor and Francis, London, UK.

Rowland J.M. (2003) Male horn dimorphism, phylogeny and systematics of rhinoceros beetles of the genus Xylotrupes (Scarabaeidae: Coleoptera). Austral. J. Zool. 51: 213-258.

Sharma S. (2003) Municipal solid waste management through vermicomposting employing exotic and local species of earthworms. Biores. Tech. 90: 169-173.

Suthar S. (2009) Vermistabilization of municipal sewage sludge amended with sugarcane trash using epigeic Eisenia fetida (Oligochaeta). J. Hazard. Mater. 163: 199-206.

Suthar S. (2010) Pilot-scale vermireactors for sewage sludge stabilization and metal remediation process: comparison with small-scale vermireactors. Ecol. Engin. 36: 703-712.

Suthar S., Singh S. (2008) Feasibility of vermicomposting in biostabilization of sludge from a distillery industry. Sci. Total Environ. 394: 237-243.

USEPA.(1994) Land application of sewage sludge - a guide for land appliers on the requirements of the federal standards for the use or disposal of sewage sludge. United States Environmental Protection Agency, Washington.

Verdonck O., De Boodt M., Gabriels R. (1987) Compost as a growing medium for horticultural plants. [in:] Compost: production, quality and use. Ed. De Bertoldi M., Ferranti M.P., Hermite P.L., Zucconi P. Elsevier Applied Science, London: 399-405.

Wang Y., Han W., Wang X., Chen H., Zhu F., Wang X., Lei C. (2017) Speciation of heavy metals and bacteria in cow dung after vermicomposting by the earthworm, Eisenia fetida. Biores. Technol. 245: 411-418.

Whittle A.J., Dyson A.J. (2002) The fate of heavy metals in green waste composting. Environmentalist 22: 13-21.

Wong J., Selvam A. (2006) Speciation of heavy metals during co-composting of sewage sludge with lime. Chemosphere 63: $980-986$ 